\title{
Social Skill Development In The Game Oray-orayan Traditional Children Of West Java
}

\author{
Sri Nurhayati ${ }^{*}$, CiptaRumsari ${ }^{2}$ \\ Shrie33@yahoo.com,nengcipta@gmail.com \\ ${ }^{1-2}$ IKIP Siliwangi, Indonesia \\ Shrie33@yahoo.com
}

\begin{abstract}
Oray-orayan game is one of the traditional games that are popular in the Kindergarten Anak Ceria Antapani District of Bandung. Oray-orayan game contains aspects of social skills. On that basis, this study aims to reveal the role of game oray-orayan in developing children's social skills, such as social interaction, cooperation, resource-saving, and concern for others. This study uses a case study method. Data was collected through interviews, observation, and documentation. These results indicate that; 1) the skills to express themselves; 2) their skills in interacting with her child 3) their skills in working together; 4) their skills in following the rules (discipline); and 5) the children's skills in empathy. Oray-orayan traditional game done in free time raises the child's social skills in their play activities and games can be an alternative that can be done indoors and outdoors. Based on this research, recommended that traditional games can be incorporated into early childhood learning, so it is not just a game for leisure only.
\end{abstract}

Keywords: social skills, traditional games, oray-orayan

\section{Introduction}

West Java is one of the provinces in Indonesia which has a wealth of tradition, cultural diversity, through a variety of local wisdom that is deeply entrenched in society. The cultural wealth and traditions implicated in diverse sub-cultures that exist in West Java, from the social system, the arts, the shape of the building (artifacts), handicrafts, culinary preparations, including types of traditional children's games. In connection with the traditional children's games, which in West Java called "kaulinanbudakbaheula", which means the game of old.

Various games can enhance creativity, one of which is a traditional game. The traditional game is a symbol of knowledge from generation to generation and has varying functions or message behind it. The traditional game is the result of great cultural value to children in order to fantasize, recreation, creative, exercising the same time as a means of training for social life, skills, courtesy, and dexterity. Here are the kinds of games that might still mostly done by children, namely Bebentengan, Congklak, Dogdog Karbit, Ecor, Gatrik, Kobak, Meow Bangkok, Ngadu Karbit, Ngadu Muncang, Oray-orayan, Pal-Palan, Prang Pring, Pacublek-Cublek Suweng, SarSur, Serok, Susumputan, Gurih, Encom, Ucing Kalangkeng, Ucing Peungpeun, Ucing Kuriling, and Galah Bandung.

Children cannot be detached from the world play,Play is a method that can not be abandoned in early childhood, children will get joy and expression freely when playing. The initial stage of growth and development in human life the most important and fundamental is in early childhood. This period is characterized by a variety of important periods such as in the golden period in which all of the potentials that exist in children develop very quickly. So that the child should be given a variety of stimulation so that the potential development of the well.

Given how crucial education for children as well as the importance and the basic stimuli that required children to develop their potential, then the play becomes a very important activity and is the hub for all activities for play activities is a necessity for children and appropriate to developments owned by children. Interactions that occur when children perform traditional games provide opportunities for children to develop social skills, language skills, and the ability of emotion[1]. 
Playing as a means of developing social skills children are expected to provide an opportunity to explore, discover, express feelings, creativity and learning fun. Social skills are a primary requirement needs to have children as a preparation for independence in later life level, it is useful in daily life both within the family and the surrounding environment.

Social skill is the ability of individuals to realize an interactive network with others and the ability to solve problems so that the acclimatization to retrieve a harmonious society [2]. Social skill is the ability to communicate, collaborate, share, participate, and adapt (sympathy, empathy, able to solve the problems and discipline by the order of values and ethics that apply) [3]

This type of game can generally be classified into two types of modern games and traditional games. The phenomenon of the modern game has given birth to an idea of the importance of re-introducing traditional children. types of games on a game activity that grows and develops in a particular area, which is currently with the values of the culture and values of community life and taught generations from one generation to next generation. The game is played by children simultaneously, in groups, to cooperate in achieving the goals of a game with rules that have been set. Not all types of traditional games can be played for children of all ages.

According to Bishop \& Curtis cited by Hidayat defines that traditional games are games that have been passed down from one generation to the next with the game contains the value of good, positive, valuable and desirable [4]. While Kurniati [5] explains that:

"Traditional game is a playing activity that grows and develops in Certain areas, which is full of cultural values and values of community life and hereditary taught from one generation to the next. From this game, children will be able to develop Reviews their potential, gain useful and meaningful experience, to be able to build relationships with Reviews their peers, increase of vocabulary, and be able to express the suppressed feelings and love while preserving the culture of the nation ".

This definition indicates that the traditional game form of activity that is handed down from one generation to the next and continuously performed by most people.

Of indicators of social skills which can be observed in the activities of traditional games are 7 aspects, namely: skills in collaboration, skills in adjusting themselves, skills in interacting, skills in self-control, skills in empathy, skills in obeying the rules, and skills in respect other [1]. One of the traditional games is a game oray-orayan. Oray-orayan including the types of games that exist in the region of West Java, Sunda. The word is derived from the Sundanese oray which means snake. Meanwhile, oray-orayan is word repeatedly put the suffix "an" which means it mimics resemble oray or snakes. The game is done in a way that resembles the way the passage of a snake[6]. Children who follow the game would form a line that long. Then sing songs orayorayan and children who became head of the snake will catch the hindmost.

The results of the study of prosocial values in traditional games Oray-orayan conducted by Yanti and Yusnaini revealed some conclusions, among others:

(1) Existence oray-orayan games in an educational context reflect the various aspects that have benefits for capital or preparation part of life children in the community.

(2) The essence of the oray-orayan games is the creative and cheerful elements (verbal) so as to give the actors an opportunity to be involved in playing together this is revealed gesturally a question and answer dialog (mutual shouting) through the song being sung.Actualization orayan-oray games attaching a child with nature (spatial) is an important part of the process of introducing children to the natural environment, and the environment.

(3) Joy to children who play them, there is also educational value that instills certain attitudes to foster a spirit of togetherness and cooperation, mutual respect and caring.

(4) Unidentified prosocial values in the game oray-orayan primary school in the form of learning activities to comfort each other, help each other, friendship, help, sacrifice, generosity, sharing, and learning community.

(5) Implementation oray-orayangames on learning in the classroom has the potential to be used as the development of primary school children's behavior, such as friendship, sharing, sacrifice[7]. 


\section{Research Method}

The method used in this study was the case study. Theoretically, a case study strategies and research methods that carefully examines a program, event, activity, process, or group of individuals. In practical terms, the case study method is used to understand and unravel the social skill values contained in oray-orayan traditional games played in Kindergarten Anak Ceria Bandung, West Java.

Selection of the type of game and the focus of the study is based on first consideration, game oray-orayan a traditional game typical of West Java. Second, games oray-orayan practically played by children in Kindergarten Anak Ceria with implications on the values of togetherness and unity. Third, oray-orayan game often played by group A children in Kindergarten Anak Ceria.

Excavation and data collection in the study of traditional games is done by participant observation. In practice, this partisipstif observation made by observing the five objects of observation in the focus of the study, namely in KindergartenAnak Ceria. The object of these observations: 1) the actor, the son of group A in Kindergarten Anak Ceria; 2) activity, namely the activities of traditional games are games oray-orayan; 3 ) act, the act of children in traditional games; 4) event, the circuit activities in traditional games; 5) feeling, expression of children in activities traditional games.

\section{Result and Discussion}

\subsection{Result}

Based on the results of data mining, observation, and analysis of the activities of traditional games that are liked by the students in KindergartenAnak Ceria in the form of game oray-orayan.
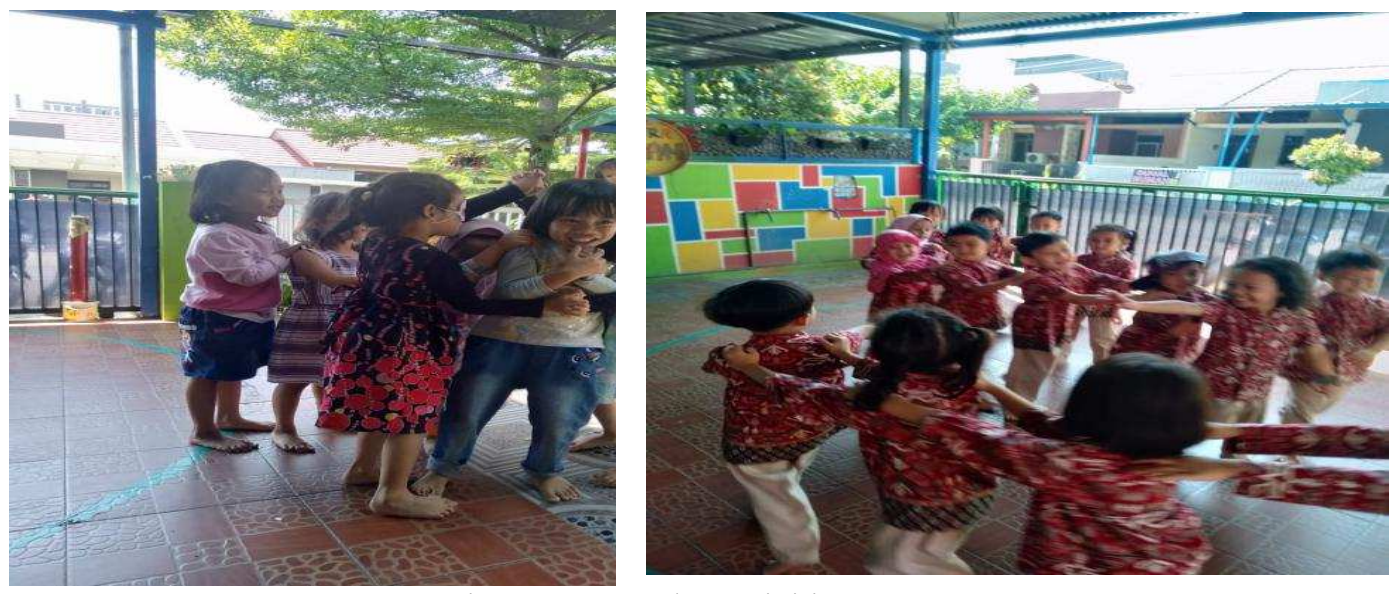

Figure 1. oray-play activities orayan

The procedure of the game:

(1) Children from a line. Generally, children who participated in the stacking based on height. The highest child positioned in front of the head of the snake, while in the last part (tail) of the children are shorter but have the characteristic deft.

(2) At the time of marching all members holding each other by using both hands holding the child's waist or shoulders in front of him. The handgrip must be strong so it is not easy lep as.

(3) Once everything is ready for the children to sing the following song.

Oray-orayan luar leor mapay sawah

Entong kasawah parena keur sumedeng beukah

Oray-orayan luar loer mapay sawah

Entong kasawah parena keur sumedeng beukah

Mendi ge teuleum 


\section{Di leuwi loba nu mandi}

Saha nu mandi

Anu mandina pandeuri..ri..ri..ri

(4) At the time of pandeuri..ri..ri..ri..ri words, children who become snack tail will soon be swept up by the head of the snake and the tail can be continued to avoid so as not to be arrested, but otherwise, the head will continue to try to catch the tail the.

(5) If the child is in the position of the tail is caught, then he should come out of this game.

(6) The game is continued until the number of members is in a row staying yan 2.

(7) If so, then the players will form a new row to redo his game.

From oray-orayan play activities, then found some realities and facts about social skills contained therein based on a review of aspects of social skills, namely:

a. The ability to express themselves

The excerpts of interviews with children; the question is why like playing oray-orayan, the answer is "because of it better and love". how the game how, he replied: "line later captured, the next most caught the hindmost". Ability that appears when it is the ability to express feelings of pleasure in playing.

b. Skills in interacting

At the time of observation, there is a child who plays the teacher invites orany-orayan at break time that is played outside the classroom. Later the teacher tells the child to bring friends to another, eventually was taken away play oray-orayan like in the picture above activities. Ability appears that the ability to interact, the ability to communicate or dialogue.

c. Skills in collaboration

At the time of the game, between the players holding each shoulder one shoulder to the other. At the time the head of the snake tail prey opponent in the back, then a friend of the group ranks will help and strengthen handle to each other to keep being disconnected from the line.

d. Skills in obeying the rules (discipline)

In the game there oray-orayan game procedures have been agreed. During play, each child is seen to follow established procedures. Like, when the tail of one of these snakes snake's head hits the opponent, it will automatically become the tail that acts can continue the game. They will come out of the areas of the game, broke away and wait for the next game.

e. Skills in empathy

At the end of the game, there is a winning group and the group that failed. They will show a sense of fun at the time of his success, but not infrequently they also denounced his friend who failed to win.

\subsection{Discussion}

Basically, traditional games have positive values that can help various aspects of early childhood development. As revealed Syaodih in Kurniatin said that social development in childhood takes place through relationships between friends in various forms of the game [1]. From the results of these studies showed that in particular the basic capabilities younger children in Kindergarten Anak Ceria can be developed through traditional games oray-orayan the ability to ability to express feelings of pleasure in play, the skills to interact or play with peers and play alternately, skills in self-control, skills in obeying regulations, as well as skills in empathy.

Skills express yourself visible from interviews and observations with children who showed a sense of excitement. This is by the opinion of Noffia \& Margaretha which states that play is the work that is fun for children, because when children play children will feel happy and the children did not feel compelled to play performed by children[8].

Skills in interacting shown by their attitude to invite more friends to play with, where there is a division of the group or team so that the child can communicate with their friends. Skills in collaboration shown by their attitude jointly develop strategies to remain in single file, keeping each other and help each other. The emergence of an attitude to help a friend in solving the problems faced demanding games.Oray-orayan game that requires member banya in the play, has more intent on deepening interaction skills players to be able to socialize and cooperate with each player. 
Skills obey the rules of sportsmanship shown by their play. Children can understand and obey the rules of the game in the play oray-orayan. Skill is needed when a child in real life, they can comply with regulations applicable to the rules in society. Empathizing skills shown by their attitude to reward other people who get the achievement, as well as having a caring attitude towards others who are experiencing difficulties.

Oray-orayan traditional game gives a positive value to the development of the social skills of children. As revealed by Arikunto cited by Halim found in traditional games children are educational values they contain although not directly visible. The educational values have many dimensions, such as a sense of togetherness, honesty, discipline, courtesy, mutual assistance, and other aspects of personality [9].

The values that can be taken from the traditional gameoray-orayan include the following:

1) The value of early detection to find children who have problems

2) Value for good physical development. Physical activity includes activities to exercise, improve coordination and balance, and develop skills in growing children.

3) Values for good mental health, which helps children effectively communicate their feelings in a natural way, reduce anxiety, self-control, concentration training.

4) Value problem solving, children learn to solve the problem so such capabilities can be transferred in real life.

5) Social values, children learn social skills, children learn social skills that will be useful for the stock in real life.

As forshortage in the game oray-orayan carried children in Kindergarten Anak Ceria is the lack of support from teachers who think this game is just as playing in your spare time only. When the game is done, the children did not receive meaningful supervision of the teacher. Teachers still can not implement traditional games into the learning process.

\section{Conclusion}

Traditional games, in general, give joy to the children who do. From this game, children will be able to develop their potential, gain experience useful and meaningful, able to build relationships with their peers, increasing the treasury said, and be able to distribute the depressed feelings while preserving and love the culture of the nation.

Oray-orayan traditional gameshows that the traditional children's games can stimulate children in developing cooperation, help children to adjust, interacting positively, can condition the child in self-control, develop empathy towards a friend, obey the rules, other and respect people. Thus, it is understood that traditional games can provide excellent impact in helping develop emotional and social skills of children.Based on this research, recommended that traditional games can be incorporated into early childhood learning, so it is not just a game for leisure only.

\section{Reference}

[1] E. Kurniati, (2011), Program Bimbingan Untuk Mengembangkan, Surakarta: Skripsi Universitas Muhammadiyah Surakarta, 1-18.

[2] E. I. B. Muhammad Mushfi, (2017), Model Interaksi Sosial Dalam Mengelaborasi Keterampilan Sosial, J. Pedagogy., 4 (2), pp.211-277.

[3] D. Rahayu, S. I. Hamid, and A. Sutini, (2016), Peningkatan Keterampilan Sosial Anak Usia Dini melalui Permainan Tradisional, Cakrawala Dini, 7 (2).

[4] D. Hidayat, (2013), Permainan Tradisional Dan Kearifan Lokal Kampung Dukuh Garut Selatan Jawa Barat, J. Acad., 5 (2), pp.1057-1070.

[5] E. Kurniati, (2016), Permainan tradisional dan perannya dalam mengembangkan keterampilan sosial anak". Kencana.

[6] P. R. Noviati and S. F. Giwangsa, (2018), Analisis Permainan Oray-orayan Terhadap Aspek Perkembangan Anak Analysis of Orayan-Orayan Games on Children' S, Jurnal Lensa Pendas, 3 (2), pp.73-78. 
[7] M. Yanti and Y. Yusnaini, (2018), The Narration Of Digital Literacy Movement In Indonesia, INFORMASI.

[8] I. Noffia and M. S. Yuliariatiningsih, (2016), Mengembangkan Disiplin Anak Usia Dini Melalui Permainan Tradisional, Cakrawala Dini J. Pendidik. Anak Usia Dini, 6 (2).

[9] F. M. Halim, (2014), Interior Museum Permainan Anak-Anak Tradisional Jawa di Surabaya," Intra, 2(2), pp.826-833. 